\title{
PENGARUH COOPERATIVE PROJECT-BASED LEARNING \\ TERHADAP MOTIVASI DAN HASIL BELAJAR PRAKTIK "PERBAIKAN MOTOR OTOMOTIF" DI SMKN 1 SEYEGAN
}

\author{
Tafakur \\ Fakultas Teknik Universitas Negeri Yogyakarta \\ tafakur_oto@yahoo.com \\ Wardan Suyanto \\ Universitas Negeri Yogyakarta \\ wardansuyanto@uny.ac.id.
}

\begin{abstract}
Abstrak
Penelitian ini bertujuan untuk mengetahui pengaruh penerapan cooperative project-based learning terhadap motivasi dan hasil belajar siswa pada praktik"Menentukan dan memperbaiki gangguan pada sistem kerja mesin". Penelitian ini menggunakan pendekatan quasi-experiment dengan desain non equivalent control group. Populasi dalam penelitian ini adalah siswa kelas XII Teknik Kendaraan Ringan SMKN 1 Seyegan Tahun 2013/2014. Sampel penelitian dipilih melalui intact group, terdiri atas kelas XII TKR3 yang diberi perlakuan cooperative project-based learning sebagai kelas eksperimen dan kelas XII TKR2 yang diterapkan pembelajaran langsung sebagai kelas kontrol. Data dikumpulkan menggunakan angket, observasi, tes praktik, dan dokumentasi, kemudian dianalisis menggunakan uji $t$ sampel bebas dan analisis kovarian (ANAKOVA). Hasil penelitian ini menunjukkan bahwa motivasi maupun hasil belajar siswa yang mengikuti cooperative projectbased learning lebih baik dibandingkan siswa yang mengikuti pembelajaran langsung seperti yang dilaksanakan selama ini.
\end{abstract}

Kata kunci: cooperative project-based learning, motivasi belajar, hasil belajar

\section{THE EFFECTS OF COOPERATIVE PROJECT-BASED LEARNING ON LEARNING MOTIVATION AND ACHIEVEMENT IN PRACTICE "AUTOMOTIVE MOTOR" IN SMKN 1 SEYEGAN}

\begin{abstract}
This study aims to investigate the effect of cooperative project-based learning implementation on student s learning motivation and achievement in practice "Determining and solving problems of engine working systems". This research using a quasi-experiment method with equivalent control group design. The population of this research consists of year XII students of TKR major in SMKN 1 Seyegan in the 2013/2014 academic year. A sample was established using intact group which consists of XII TKR 2 class were taught using cooperative project-based learning strategy as experimental group and XII TKR 3 class were taught using direct instruction strategy as control group. The data were collected through questionnaire, observation, performance test and documentation then were analyzed using the independent sample t test and analysis of covariance (ANCOVA). This study concluded that students who follow the cooperative project-based learning are more motivated and achieve better learning outcomes than the other class who follow the direct instruction strategy.
\end{abstract}

Keywords: cooperative project-based learning, student's learning motivation, student 's achievement. 


\section{PENDAHULUAN}

Persaingan kerja di dunia global bukan merupakan bahan pembicaraan yang jarang didengar di dunia kejuruan. Tuntutan persaingan merupakan konsekuensi bagi setiap angkatan kerja khususnya lulusan Sekolah Menengah Kejuruan (SMK). Fakta ini menunjuk pada kebutuhan perkembangan dunia kerja di abad 21 yang menuntut keterampilan dalam belajar dan berinovasi, keterampilan dalam mengakses informasi, media, dan teknologi, serta keterampilan hidup dan karier bagi siapa saja yang ingin menjaga eksistensinya di dunia kerja (The Partnership for 21st Century Skills, 2008, pp.1-9). Oleh karena itu, bukan hal yang asing bahwa kemampuan berfikir kritis, memecahkan masalah, berkolaborasi, kepemimpinan, ketangkasan, beradaptasi, inisiatif, berkomunikasi lisan dan tulisan, mengakses informasi, keingintahuan maupun berimajinasi merupakan kebutuhan utama.

Sebagai jalur pendidikan pencetak tenaga kerja, SMK memiliki tujuan khusus. Sesuai dengan lampiran Peraturan Menteri Pendidikan Nasional Nomor 23 Tahun 2006, "Pendidikan menengah kejuruan terdiri atas SMK (Sekolah Menengah Kejuruan) dan MAK (Madrasah Aliyah Kejuruan) yang bertujuan meningkatkan kecerdasan, pengetahuan, kepribadian, akhlak mulia, serta keterampilan untuk hidup mandiri dan mengikuti pendidikan lebih lanjut sesuai dengan kejuruannya". Dengan demikian, SMK diharapkan menghasilkan lulusan kompetitif untuk bekerja maupun melanjutkan pendidikan.

Salah satu bidang yang berkembang pesat sebagai lahan kerja di Indonesia adalah bidang otomotif. Tercermin dari hasil penjualan mobil di Indonesia tahun 2012 telah meningkat menjadi 816.322 unit atau meningkat 23,7 $\%$ dibanding tahun 2011 dan diprediksi akan terus meningkat (http://otomotif.kompas. com). Tantangan ini harus segera diantisipasi dalam pembelajaran di SMK, sehingga mampu mencetak lulusan yang tidak hanya ikut bersaing, namun mampu memenangkan persaingan tenaga kerja.

Tuntutan kompetensi harus selalu menjadi orientasi pembelajaran di SMK. Setiap kompetensi terkadang memiliki karakteristik berbeda. Standar kompetensi "Menentukan dan memperbaiki gangguan pada sistem kerja mesin"menuntutkemampuan mengidentifikasi, pengukuran dan pemeriksaan, menyimpulkan kerusakan, serta memperbaiki mesin. Siswa dituntut mengkonstruksikan skill dasar dan pengetahuannya pada praktik.

Kondisi yang berlangsung selama ini, pencapaian kompetensi siswa belum sesuai yang diharapkan. Hasil tes praktik tahun 2012 menunjukkan bahwa siswa belum memiliki kemampuan menyimpulkan kerusakan dan perbaikan mesin secara tuntas. Lebih dari 40\% siswa belum mampu mencapai Kriteria Ketuntasan Mimimm (KKM) yang ditetapkan. Secara detail, 31\% siswa belum mampu pada bagian sistem pendingin, serta $41 \%$ siswa belum berhasil pada sistem pengapian. Tentu saja, kondisi ini mengindikasikan bahwa terdapat masalah pada pembelajarannya.

Proses pembelajaran jelas berpengaruh langsung pada hasil belajar di atas. Faktanya, siswa cenderung tergantung pada guru, serta kerusakan dapat diidentifikasi namun tidak berdasarkan data. Hasilnya, perbaikan yang dilakukan tidak tuntas. Kondisi lainnya ketika pembelajaran berlangsung, siswa banyak melakukan kegiatan di luar pembelajaran, seperti bermain dongkrak, HP, bermalasmalasan, serta bersenda gurau di ruang kerja. Tentu saja hal ini sangat menghambat proses pembelajaran. Oleh karena itu, perlu perbaikan agar pembelajaran mampu membangkitkan motivasi belajar, serta mendukung tercapainya pembelajaran sesuai karakteristik materi di atas.

Selama ini, guru mengelola pembelajaran dengan tahap persiapan, memperagakan atau demonstrasi, kemudian siswa menirukan saat praktik, serta siswa melakukan praktik mandiri. Guru menerapkan pembelajaran langsung seperti mengajar siswa kelas XI. Namun, menurut Muijs \& Reynolds (2011, p.50) strategi tersebut cenderung: (1) kurang efektif untuk target pembelajaran yang komplek,(2) hanya cocok untuk siswa berlatar belakang rendah, (3) membuat siswa tergantung pada guru dan pasif, (4) cenderung sesuai untuk kelas awal, (5) interaksi siswa cenderung rendah, dan (6) beberapa tujuan pembelajaran sulit dicapai. Hasilnya, guru kesulitan pada pembelajaran praktik selama ini. Dengan demikian, praktik 
"Menentukan dan memperbaiki gangguan pada sistem kerja mesin" yang menuntut gabungan skill dasar, menyimpulkan kerusakan dan perbaikan yang dilandasi pemecahan masalah perlu diterapkan strategi pembelajaran yang sesuai dengan karakteristik kompetensi dan siswa yang diajar.

Strategi pembelajaran perlu dipilih yang paling sesuai dengan tuntutan kompetensi serta karakteristik siswa yang diajar. Salah satu pendekatannya adalah konstruktivistik. Pembelajaran konstruktivistik dimulai dari adanya kasus, pertanyaan, atau permasalahan (Cooperstein dan Weidinger, 2004, pp.141148). Strategi pembelajaran konstruktivistik yang mengkonstruksikan skill dasar serta berorientasi pada proses dan hasil adalah pembelajaran berbasis proyek (projectbased learning). Borich (2007, p.359) mengatakan bahwa pembelajaran ini memiliki karakteristik: (1) Berdurasi yang cukup lama, (2) menghubungkan beberapa disiplin ilmu, (3) berfokus pada proses dan hasil, serta (4) melibatkan guru sebagai pelatih dan kolaborasi. Di samping itu, pembelajaran ini memiliki keuntungan dapat mendorong motivasi selama memecahkan masalah, merencana, dan mengarahkan proyeknya (Tippelt \& Amoros, 2003 , p. 19). Pembelajaran berbasis proyek memungkinkan siswa mengkonstruksikan pengetahuan dan keterampilan sehingga cocok untuk praktik "Menentukan dan memperbaiki gangguan pada sistem kerja mesin". Diperlukan pula kerjasama sehingga pembelajaran dapat dilaksanakan dengan kegiatan kerja kelompok secara terstruktur.

Pembelajaran berbasis proyek yang dilaksanakan secara kooperatif diharapkan sesuai diterapkan pada karakteristik materi kompleks dan gabungan dari skill dasar, berorientasi pada proses dan hasil serta mampu mengembangkan kerjasama dan kolaborasi. Pembelajaran ini diharapkan mendorong motivasi belajar siswa serta membantu siswa mencapai tujuan pembelajaran yang diharapkan pada standar kompetensi di atas.

\section{Cooperative Project-Based Learning}

Cooperative project-based learning merupakan pembelajaran yang menginte- grasikan pembelajaran berbasis proyek yang dilaksanakan dengan strategi pembelajaran kooperatif (Lazinica dan Calafate, 2009, p.395). Pembelajaran ini dilakukan dengan fase pembelajaran berbasis proyek dengan bentuk kerja sama kelompok melalui pendekatan kooperatif. Bender (2012, p.148) mengatakan bahwa ketika guru menggunakan pembelajaran berbasis proyek dengan cara yang berdiri sendiri, siswa kurang memiliki kemampuan untuk berkooperatif sehingga pembelajaran kooperatif diperlukan pula dalam melaksanakan tugas pada pembelajaran berbasis proyek. Dalam pelaksanaannya, penugasan pada pembelajaran kooperatif dapat diimplementasikan sebagai pembelajaran yang kecil dalam proyek di pembelajaran berbasis proyek, dengan berdurasi lama maupun diselesaikan dalam satu waktu pertemuan. Dengan demikian, pembelajaran kooperatif dapat diintegrasikan dengan pembelajaran berbasis proyek.

Selainitu,Bender(2012,p.147)mengatakan pula bahwa pembelajaran kooperatif dapat menumbuhkan siswa untuk bekerjasama membangun setiap pemahamannya dengan siswa lain. Menurutnya, "Teacher moving toward PBL instruction should understand that student will need cooperative learning skills for the PBL instruction to be effective". Oleh karena itu, integrasi ini memberi keuntungan jika dibanding proyek yang dikerjakan secara individu atau kelompok tanpa strukturisasi yang mendukung.

Pembelajaran cooperative (cooperative learning) sendiri adalah strategi pembelajaran tidak langsung (indirect instruction) yang menekankan pada kerja kelompok untuk mencapai tujuan pembelajaran dengan saling membantu dan mendukung satu dengan yang lain (Rüütmann \& Kipper, 2011, p.110). Pembelajaran kooperatif mampu mendukung keaktifan siswa, kerjasama dan pemberian umpan baik antar siswa untuk saling mendorong dalam pembelajaran. Hal ini didukung oleh Wlodkowsky (2008, p.7) bahwa: "motivated learner care more and concentrate better while they expend effort, and they are more cooperative". Dengan demikian, pembelajaran kooperatif mendorong motivasi maupun usaha 
siswa untuk belajar, sehingga mencapai hasil belajar seperti yang diharapkan.

Seperti pembelajaran kooperatif, pembelajaran berbasis proyek juga merupakan kategori strategi pembelajaran tidak langsung (Rüütmann \& Kipper, 2011, p.110). Pembelajaran berbasis proyek memberikan tugas yang berasal dari masalah. Siswa dituntut melakukan pemecahan permasalahan autentik serta mengembangkan keterampilan dan pengetahuan secara mandiri. Pembelajaran ini berorientasi pada hasil. Borich (2007, p.365) dalam bukunya menyatakan bahwa: "Projectbased learning is an approach to learning that promotes intrinsic motivation by organizing instruction around tasks most likely to induce and support learner interest, effort, and persistence". Oleh karena itu pembelajaran berbasis proyek dapat mendukung motivasi maupun usaha siswa dalam belajar dengan berorientasi pada proses dan hasil akhir.

Tippelt \& Amoros (2003, p.11), mengemukakan bahwa fase pembelajaran berbasis proyek, meliputi: menginformasikan (informing), merencana (planning), memutuskan (deciding), menerapkan (implementing), mengontrol (controlling), dan mengevaluasi (evaluating). Oleh karena itu, dalam pembelajaran praktik "Menentukan dan memperbaiki sistem kerja mesin" pada tahap penginformasian siswa diinformasikan mengenai masalah pada mesin. Pada tahap perencanaan guru merumuskan tujuan, strategi, lembar kerja (job sheet), merancang kebutuhan sumber belajar, dan merancang alat evaluasi. Pada tahap menentukan, guru membantu mengidentifikasi masalah mesin serta menyusun rencana kerja yang akan dilakukan siswa. Pada tahap menerapkan, siswa melaksanakan tugas proyek yang telah disusun. Pada tahap pengontrolan, guru dan siswa mengontrol perkembangan proyek. Pada tahap evaluasi, guru melaksanakan evaluasi praktik kompetensi "Menentukan dan memperbaiki gangguan pada sistem kerja mesin".

Pembelajaran berbasis proyek mengarahkan pembelajaran sehingga memperoleh hasil yang nyata secara individu atau kelompok, sedangkan pembelajaran kooperatif memberi kesempatan siswa untuk bekerja sama dan kolaborasi dalam kegiatan kelompok. Pembelajaran kooperatif untuk melaksanakan kerja kelompoknya dapat dipilih pendekatan yang sesuai seperti group investigation. Pendekatan kelompok ini memiliki langkah-langkah: (1) pengelompokan, (2) perencanaan tugas belajar, (3) pelaksanaan kegiatan penelitian sampai diskusi kelompok dan menyimpulkan hasil investigasi, (4) mengorganisasi hasil akhir, (5) presentasi penelitian, dan (6) evaluasi. (Arends \& Kilcher, 2010, p.318)

\section{Pembelajaran langsung (direct instruction)}

Pembelajaran langsung (direct instruction) merupakan strategi yang juga diketahui sebagai "active teaching" atau "whole class teaching" yang berarti gaya mengajar di mana guru aktif mengajak dalam membawakan materi pelajaran kepada siswa dengan mengajar keseluruhan kelas secara langsung (Mujs \& Reynolds, 2011, p.35). kegiatan pembelajaran ini dipusatkan pada aktivitas guru. Hal ini juga disampaikan Killen (2009, p.118) bahwa pembelajaran langsung dapat diartikan sebagai teknik mengajar secara ekspositori, sehingga dipandang efektif dalam membelajarkan praktik kejuruan untuk melatih keterampilan dasar.

Sebaliknya, pembelajaran langsung memiliki beberapa kelemahan. Muijs \& Reynolds (2011, p.50) menyebutkannya antara lain: (1) struktur pembelajaran langsung kurang efektif ketika target pembelajarannya lebih komplek atau "open-ended". (2) pembelajaran ini lebih cocok hanya untuk siswa yang berlatarbelakang lemah dan prestasi rendah, (3) aturannya membuat siswa terlalu pasif, ketergantungan pada guru, dan tidak berkembangnya kemampuan belajar bebasnya, (4) condong mengarah pada siswa kelas awal, (5) interaksi dengan siswa cenderung rendah, dan (6) pembelajaran langsung secara tradisional tidak pas untuk beberapa tujuan pembelajaran. Oleh karena itu, pembelajaran langsung masih sulit diterapkan pada praktik "Menentukan dan memperbaiki gangguan pada sistem kerja mesin".

Pembelajaran langsung memiliki beberapa langkah. Arends \& Killcher 
(2010, p.195) mengatakan bahwa langkah pembelajaran langsung yaitu: (1) menarik perhatian dan menjelaskan tujuan pelajaran, (2) mendemonstrasikan keterampilan, (3) menyediakan kesempatan kepada siswa untuk mengikuti praktik (praktik terbimbing), (4) mengecek pemahaman dan memberi umpan balik, (5) siswa melakukan praktik secara bebas, dan (6) menutup pelajaran.

\section{Motivasi Belajar}

Sardiman (2011, p.73) menjelaskan bahwa "motivasi dapat diartikan sebagai daya penggerak yang telah menjadi aktif". Motivasi membawa siswa ke arah tujuan, sehingga siswa yang memiliki motivasi yang tinggi akan cenderung memiliki keinginan untuk mencapai prestasi. Demikian pula disampaikan Wlodkowsky (2008, p.2) menyebutkan bahwa: "motivation binds emotion to action", sehingga motivasi secara emosional akan membawa siswa untuk melaksanakan kegiatan tertentu. Schunk, Pintrich, \& Meece (2010, p.11) mengemukakan bahwa motivasi dapat ditunjukkan oleh 4 indikator, yaitu ketertarikan terhadap suatu tugas, usaha, ketekunan dan pencapaian prestasi. Motivasi merupakan hal yang sangat esensial dalam pembelajaran. Dengan demikian, dalam pembelajaran praktik, siswa yang memiliki motivasi belajar dapat dilihat dari: (1) ketertarikan untuk belajar dan mengikuti pembelajaran praktik secara mandiri, (2) ketekunan dan usaha untuk belajar walau menghadapi kesulitan atau kebosanan, dan (3) keinginan untuk mencapai dan mempertahankan prestasi.

Motivasi belajar siswa tidak sematamata dimiliki dari tubuhnya sendiri. Namun, tumbuhnya motivasi belajar siswa dipengaruhi oleh berbagai macam faktor, yaitu faktor personal dan sosiokultural, faktor lingkungan belajar, serta faktor persepsi dan keyakinan siswa terhadap pembelajaran, keluarga, maupun dari diri siswa. Dalam pembelajaran praktik, lingkungan belajar di sekolah memiliki peran yang kuat terhadap motivasi belajar siswa. Strategi pembelajaran, hubungan pertemanan, hubungan dengan guru, maupun kondisi kelas merupakan faktor yang dapat mempengaruhi motivasi belajar siswa.

\section{Hasil Belajar Praktik}

Uno (2008, p.16) mengemukakan bahwa hasil belajar merupakan bentuk penguasaan kemampuan atau keterampilan sebagai perubahan kapabilitas (kemampuan tertentu) sebagai akibat setelah siswa mengikuti serangkaian kegiatan belajar. Hasil belajar merupakan perubahan perilaku yang diharapkan dalam bentuk kemampuan dan penguasaan tujuan instruksional oleh siswa setelah melakukan aktivitas belajar. Krathwohl, Bloom \& Masia (1965, p.7) membagi hasil belajar menjadi 3 ranah, yaitu ranah kognitif, afektif, dan psikomotorik. Ranah kognitif berkaitan dengan pengetahuan, afektif berkaitan dengan sikap, dan psikomotorik berkaitan dengan keterampilan.

Hasil belajar merupakan kemampuan yang diharapkan pada kompetensi tertentu setelah siswa mengikuti pembelajaran. Standar kompetensi "Menentukan dan memperbaiki gangguan pada sistem kerja mesin" menuntut kemampuan mengidentifikasi komponen yang rusak melalui pemeriksaan dan pengukuran, mengakses spesifikasi ukuran, menyimpulkan kerusakan, serta melakukan perbaikan secara tuntas pada mesin. Dengan demikian, hasil belajar pada praktik tersebut berupa kemampuan kinerja praktik oleh siswa sesuai standar yang ditentukan. Penguasaan skill pada pembelajaran praktik tersebut dapat dilihat dari ketercapaian penguasaan siswa terhadap skillskill sesuai indikator ketercapaian kompetensi, meliputi penguasaan dan kesesuaian prosedur menentukan kerusakan, pencapaian langkah kerja pemeriksaan dan perbaikan, penguasaan prosedur perbaikan dengan mengakses spesifikasi, kualitas hasil akhir dengan waktu yang telah ditentukan untuk menyelesaikan tugas praktik dari tahap persiapan, tahap proses, dan tahap akhir. Adapun tahap yang dinilai meliputi langkah persiapan, pemeriksaan atau pengukuran komponen, mengakses spesifikasi ukuran, menyimpulkan kerusakan komponen, hingga melakukan perbaikan secara tuntas.

Hasil praktik dalam bentuk performa kerja merupakan sasaran pembelajaran yang harus dilakukan penilaian untuk mengetahui ketercapaiannya. Terdapat beberapa tahapan 
dalam penilaian ini menurut Kubiszin dan Borich (2003, p.158) yaitu menentukan apa yang akan diuji, merancang suasana penilaian, menentukan rubrik penilaian, serta menentukan batasan penilaian.

Seperti halnya motivasi belajar, hasil belajar praktik dipengaruhi berbagai faktor. Hasil belajar dapat dipengaruhi oleh input siswa, instrumental input, lingkungan, serta proses yang dilaksanakan (Purwanto, 2003, p.107). Oleh karena itu, strategi pembelajaran yang diterapkan oleh guru dalam praktik akan berpengaruh secara langsung terhadap hasil belajar yang dicapai siswa. Selain hal tersebut, pembelajaran praktik secara langsung didukung oleh pembelajaran teori. Dengan demikian, hasil belajar teori "Menentukan dan memperbaiki gangguan pada sistem kerja mesin" yang mendukung pembelajaran praktik, diduga berhubungan dengan hasil belajar praktiknya.

\section{METODE PENELITIAN}

\section{Jenis Penelitian}

Penelitian ini adalah penelitian kuantitatif dengan pendekatan quasi experiment. Desain yang digunakan adalah Pretest-Posttest Non Equivalent Control Group Design.

\section{Waktu dan Tempat Penelitian}

Penelitian ini dilaksanakan di SMK Negeri 1 Seyegan kompetensi keahlian Teknik Kendaraan Ringan Kelas XII. Penelitian dilaksanakan di bengkel otomotif ruang kerja motor otomotif semester genap tahun pelajaran 2013/2014 pada bulan Januari-Februari 2014.

\section{Populasi dan Sampel Penelitian}

Populasi dalam penelitian ini meliputi siswa kelas XII kompetensi keahlian Teknik Kendaraan Ringan meliputi 3 kelas yaitu kelas XII TKR 1 dengan jumlah 33 siswa, kelas XII TKR 2 dengan jumlah 35 siswa, serta kelas XIITKR 3 dengan jumlah 31 siswa. Sampel ditentukan dengan intact group. Penentuan kelas sampelnya adalah 1 kelas untuk kelas eksperimen, 1 kelas kontrol, serta 1 kelas untuk ujicoba instrumen.

\section{Prosedur Penelitian}

Gambaran desain penelitian yang digunakan adalah sebagai berikut:

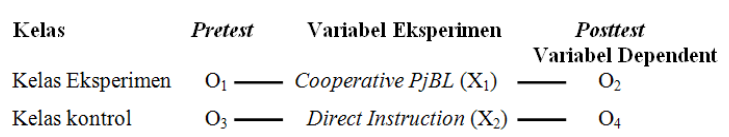

Keterangan:

$\mathrm{O}_{1}$ : Pretest motivasi belajar dan tes praktik sebelum penerapan cooperative projectbased learning (CPjBL).

$\mathrm{O}_{2}$ : Pemberian posttest setelah penerapan cooperative project-based learning.

$\mathrm{O}_{3}$ : Pretest motivasi belajar dan tes praktik sebelum penerapan pembelajaran langsung.

$\mathrm{O}_{4}$ : Posttest setelah pembelajaran langsung.

$\mathrm{X}_{1}$ : Perlakuan pada kelas eksperimen, berupa penerapan cooperative project-based learning.

$\mathrm{X}_{2}$ : Perlakuan yang diberikan kepada kelas kontrol, berupa pembelajaran langsung.

Langkah-langkah penelitian yang dilaksanakan meliputi: (1) Menyiapkan skenario pembelajaran meliputi Rencana Pelaksanaan Pembelajaran praktik (RPP), job sheet, lembar observasi tes praktik, menyusun instrumen non tes yang berupa angket motivasi belajar, serta lembar observasi keterlaksanaan pembelajaran, dan materi pembelajaran; (2) melakukan validasi instrumen; (3) melaksanakan pretest praktik pretest motivasi belajar sebelum diberikan perlakuan; (4) proses pemberian perlakuan selama 2 kali pertemuan masingmasing 8 x 45 menit; (5) pemberian posttest; (6) analisis data dan interpretasi hasilnya

\section{Data, Intrumen, dan Teknik Pengumpulan Data}

Data yang diambil meliputi motivasi belajar siswa sebelum dan setelah perlakuan, keterlaksanaan perlakuan, hasil belajar praktik siswa sebelum dan setelah perlakuan, dan hasil belajar teori siswa sebagai data kovariabel. Oleh karena itu, teknik pengumpulan data yang digunakan adalah angket, observasi, tes praktik dan dokumentasi. Instrumennya meliputi angket, lembar observasi keterlaksanaan pembelajaran, lembar observasi unjuk kerja praktik dan dokumen. 


\section{Teknik Analisis Data}

Analisis data dalam penelitian ini meliputi analisis deskriptif, uji prasyarat analisis, uji terhadap hasil pretest, dan uji hipotesis. Analisis deskriptif dilakukan untuk mengetahui nilai terendah, nilai tertinggi, rerata, median, modus, variansi, maupun simpangan baku pada setiap data kuantitatif yang terkumpul. Uji prasyarat analisis terdiri dari uji normalitas, uji homogenitas serta uji linearitas. Uji normalitas menggunakan uji Kolmogorovsmirnov, uji homogenitas dilakukan dengan uji levene, serta uji linearitas dilakukan antara nilai kovariabel dengan variabel terikat. Uji terhadap hasil pretest menggunakan uji $\mathrm{t}$ dengan membandingkan rata-rata data pretest sehingga diketahui kondisi awal dari kelompok sampel antara kelas kontrol maupun kelas eksperimen. Uji hipotesis dilakukan pada hipotesis 1 dan hipotesis 2 . Uji hipotesis 1 dilakukan dengan membandingkan motivasi belajar siswa yang menerapkan cooperative project-based learning dengan yang mengikuti pembelajaran langsung. Teknik analisis data yang digunakan adalah uji t dengan alpha $(\alpha)$ : 0,05 .Uji hipotesis 2 dilakukan dengan menguji bahwa hasil belajar siswa yang menerapkan cooperative project-based learning akan berbeda dibanding dengan yang menerapkan pembelajaran langsung pada pembelajaran praktik "Menentukan dan memperbaiki gangguan pada sistem kerja mesin" meskipun mempertimbangkan hasil belajar teorinya menggunakan analisis kovarian (ANCOVA) dengan nilai alpha $(\alpha)$ : 0,05 .

\section{HASIL PENELITIAN DAN PEMBAHASAN}

\section{Hasil Penelitian}

Penelitian dilaksanakan pada dua kelompok sampel, yaitu kelompok eksperimen dan kelompok kontrol dengan non equivalen control group design. Data yang diperoleh meliputi data pretest serta posttest baik motivasi maupun hasil belajarnya, serta hasil belajar teori sebagai kovariabel.

\section{Deskripsi Data Awal sebelum Perlakuan}

Kondisi motivasi belajar awal dapat dilihat pada tabel 1 .
Tabel 1. Statistik Kondisi Motivasi Awal

Siswa

\begin{tabular}{lcc}
\hline Statistik & K. eksperimen & K. kontrol \\
\hline Nilai terendah & 30 & 33 \\
Nilai tertinggi & 48 & 54 \\
Rata-rata & 40,032 & 41,457 \\
Median & 40 & 41 \\
Modus & 38 & 37 \\
Variansi & 15,966 & 22,844 \\
Simpangan baku & 3,9957 & 4,7795 \\
\hline
\end{tabular}

Dilihat dari skor minimal dan maksimumnya, motivasi belajar siswa awal kelas kontrol lebih tinggi daripada kelas eksperimen. Ditinjau dari median dan skor rata-ratanya, kelas eksperimen cenderung lebih tinggi. Berikutnya, Statistik deskriptif hasil pretest praktik siswa ditunjukkan pada tabel 2 .

Tabel 2. Statistik Deskriptif Hasil Pretest Praktik Siswa

\begin{tabular}{lcc}
\hline Statistik & K. eksperimen & K. kontrol \\
\hline Nilai terendah & 47,5 & 42,5 \\
Nilai tertinggi & 75 & 77,5 \\
Rata-rata & 59,68 & 58,64 \\
Median & 57,5 & 57,5 \\
Modus & 57,5 & 55 \\
Variansi & 54,89 & 64,46 \\
Simpangan baku & 7,41 & 8,03 \\
\hline
\end{tabular}

Sesuai tabel di atas, dapat dilihat bahwa skor pretest kelas kontrol memiliki pencapaian nilai tertinggi 77,5. Skor ini lebih tinggi daripada kelas eksperimen yaitu 75. Namun rata-rata kelompoknya lebih rendah dibanding kelas eksperimen yaitu $58,64<59,68$ dengan selisih keduanya tidak terpaut jauh.

Sebagai kovariabel, analisis deskriptif hasil belajar teori siswa dapat dilihat pada tabel 3 .

Tabel 3. Statistik Deskriptif Hasil Belajar Teori Siswa

\begin{tabular}{lcc}
\hline Statistik & K. eksperimen & K. kontrol \\
\hline Nilai terendah & 72 & 72 \\
Nilai tertinggi & 82 & 82 \\
Rata-rata & 77,61 & 77,03 \\
\hline
\end{tabular}


Lanjutan tabel 3.

\begin{tabular}{lcc}
\hline Median & 78 & 77 \\
Modus & 78 & 78 \\
Variansi & 5,25 & 4,50 \\
Simpangan baku & 2,29 & 2,12 \\
\hline
\end{tabular}

Sesuai tabel 3, hasil belajar teori siswa untuk kelas eksperimen cenderung lebih tinggi daripada kelas kontrol. Hal tersebut dapat dilihat dari rata-rata skornya lebih tinggi, yaitu 77,61 . Skor rata-rata ini lebih tinggi daripada kelas kontrol yaitu 77,03.

\section{Deskripsi Pelaksanaan Perlakuan}

Pembelajaran dilakukan sebanyak 4 kali pertemuan, 2 kali pretest dan posttest dan 2 kali untuk perlakuan. Setiap kelas diberi materi, media, jam praktik, suasana dan kondisi yang sama namun menggunakan strategi pembelajaran yang berbeda sesuai rancangan penelitian. Materi yang dipelajari meliputi sistem pendinginan dan sistem pengapian. Pembelajaran pada kelas eksperimen menerapkan cooperative projectbased learning, sedangkan kelas kontrol menggunakan pembelajaran langsung. Masingmasing pertemuan berdurasi $8 \times 45$ menit.

Hasil observasi oleh dua orang observer menyatakan bahwa pembelajaran dapat terlaksana sesuai dengan yang direncanakan, meskipun terdapat kendala pada perlakuan 1 untuk kelas eksperimen, yaitu terdapat sebagian siswa belum memberi umpan balik pada akhir pembelajaran karena keterbatasan waktu. Namun, kendala ini dapat teratasi pada perlakuan 2 dengan membatasi waktu menjawab bagi siswa sehingga pastisipasi siswa meningkat. Dilihat dari pelaksanaan pembelajaran pada kelas kontrol, RPP yang direncanakan dapat berjalan dengan baik. Selain itu, dilihat dari keseriusan guru saat mengajar, observer menyatakan bahwa guru cukup serius mengajar baik mengajar di kelas eksperimen maupun kelas kontrol. Guru melaksanakan pembelajaran sesuai dengan RPP serta melaksanakan tahapan pembelajaran termasuk mengontrol waktu setiap tahapannya.

\section{Deskripsi Data Akhir Setelah Perlakuan}

Setelah diberikan perlakuan, dilakukan pengambilan data motivasi belajar maupun tes praktik. Statistik deskriptif motivasi belajar siswa akhir dapat dilihat pada tabel 4.

Tabel 4. Deskripsi Motivasi Belajar Siswa setelah Perlakuan

\begin{tabular}{lcc}
\hline Statistik & K. eksperimen & K. kontrol \\
\hline Nilai terendah & 36 & 35 \\
Nilai tertinggi & 51 & 52 \\
Rata-rata & 44,94 & 43,00 \\
Median & 45 & 42 \\
Modus & 46 & 42 \\
Variansi & 11,06 & 17,59 \\
Simpangan baku & 3,33 & 4,19 \\
\hline
\end{tabular}

Sesuai tabel di atas, motivasi belajar siswa setelah perlakuan pada kelas eksperimen cenderung lebih tinggi daripada kelas kontrol, yaitu dengan rata-rata skor 44,94. Dengan demikian, motivasi belajar siswa yang mengikuti pembelajaran praktik cooperative project-based learning cenderung lebih tinggi daripada siswa yang mengikuti pembelajaran langsung.

Selain motivasi, hasil posttest secara deskriptif setelah diberikan perlakuan dapat dilihat pada tabel 5 .

Tabel 5. Statistik deskriptif hasil posttest siswa setelah perlakuan

\begin{tabular}{lcc}
\hline Statistik & K. eksperimen & K. kontrol \\
\hline Nilai terendah & 67,5 & 62,5 \\
Nilai tertinggi & 100 & 95 \\
Rata-rata & 81,13 & 76,64 \\
Median & 80 & 77,5 \\
Modus & 80 & 72.5 \\
Variansi & 58,27 & 52,92 \\
Simpangan baku & 7,63 & 7,27 \\
\hline
\end{tabular}

Sesuai dengan tabel di atas, kondisi hasil belajar praktik siswa kelas eksperimen dapat dikatakan lebih baik setelah perlakuan. Ini terlihat dari nilai rata-rata siswa yang lebih tinggi, yaitu 81,13 untuk kelas eksperimen, sedangkan 76,64 untuk kelas kontrolnya. Ditinjau dari nilai maksimalnya, pada kelas eksperimen terdapat siswa yang memperoleh nilai maksimal 100, sedangkan untuk kelas kontrolnya hanya 95. 
Tabel 6. Hasil Pengujian Normalitas Data

\begin{tabular}{lccc}
\hline Data & Strategi & p (Sig.) & Ket. \\
\hline \multirow{2}{*}{ Motivasi awal } & CPjBL & 0,200 & Normal \\
& Direct Instruction & 0,086 & Normal \\
Pretest praktik & CPjBL & 0,183 & Normal \\
& Direct Instruction & 0,200 & Normal \\
Motivasi akhir & CPjBL & 0,200 & Normal \\
& Direct Instruction & 0,094 & Normal \\
Posttest praktik & CPjBL & 0,129 & Normal \\
& Direct Instruction & 0,064 & Normal \\
Nilai teori & CPjBL & 0,083 & Normal \\
& Direct Instruction & 0,116 & Normal \\
\hline
\end{tabular}

Tabel 7. Hasil Uji Homogenitas Varians

\begin{tabular}{|c|c|c|c|}
\hline Data & Strategi & p (Sig.) & Keputusan \\
\hline Motivasi awal & $\begin{array}{c}\mathrm{CPjBL} \\
\text { Direct Instruction }\end{array}$ & 0,250 & Homogen \\
\hline Pretest praktik & $\begin{array}{c}\mathrm{CPjBL} \\
\text { Direct Instruction }\end{array}$ & 0,704 & Homogen \\
\hline Motivasi akhir & $\begin{array}{c}\text { CPjBL } \\
\text { Direct Instruction }\end{array}$ & 0,177 & Homogen \\
\hline Posttest praktik & $\begin{array}{c}\mathrm{CPjBL} \\
\text { Direct Instruction }\end{array}$ & 0,938 & Homogen \\
\hline Nilai teori & $\begin{array}{c}\text { CPjBL } \\
\text { Direct Instruction }\end{array}$ & 0,720 & Homogen \\
\hline
\end{tabular}

\section{Hasil Uji Hipotesis}

Uji hipotesis dilakukan untuk membuktikan hipotesis yang diajukan. Sebelum pengujian hipotesis, dilakukan pengujian prasyarat meliputi uji normalitas data, homogenitas, serta uji linearitas. Hasil uji normalitas masing-masing kelompok data dapat dilihat pada tabel 6 .

Berdasarkan hasil uji normalitas menggunakan program SPSS 21 di atas, dapat dilihat bahwa semua kelompok data memiliki distribusi yang normal, sehingga memenuhi salah satu prasyarat uji hipotesis menggunakan statistik yang direncanakan.

Pengujian prasyarat berikutnya adalah uji homogenitas untuk mengetahui bahwa data pada kelompok yang dibandingkan bersifat homogen atau tidak. Pengujian homogenitas dilakukan menggunakan uji Levene dengan bantuan program SPSS 21. Hasil pengujian homogenitas dapat dilihat pada tabel 7 .

Sesuai hasil uji di atas, dapat dilihat bahwa data yang dibandingkan memiliki variansi yang homogen, sehingga memenuhi satu prasyarat uji menggunakan statistik yang direncanakan.

Pengujian prasyarat berikutnya adalah uji linearitas untuk mengetahui bahwa kondisi kedua data memiliki hubungan yang linier yaitu hasil belajar teori dengan posttest hasil belajar praktik. Pengujian dilakukan dengan dengan statistik uji F. Hasil pengujian linearitas dapat dilihat pada tabel 8 dan tabel 9 .

Sesuai hasil pengujian di atas, dapat dilihat bahwa untuk kelas eksperimen maupun kelas kontrol pada deviasi linearitasnya memiliki nilai sig. lebih besar dari alpha yang ditetapkan yaitu $0,484>0,05$ dan 0,899 >0,05. Dengan demikian, dapat dikatakan bahwa terdapat 
Tabel 8. Hasil Uji Linearitas Data untuk Kelas Eksperimen

\begin{tabular}{llcc}
\hline Source & & F & Sig. \\
\hline Between Groups & (Combined) & 2,786 & 0,027 \\
& Linearity & 15,578 & 0,001 \\
& Deviation from Linearity & 0,958 & 0,484 \\
\hline
\end{tabular}

Tabel 9. Hasil Uji Linearitas Data untuk Kelas Kontrol

\begin{tabular}{llll}
\hline Source & & F & Sig. \\
\hline Between Groups & (Combined) & 3,743 & 0,005 \\
& Linearity & 27,207 & 0,000 \\
& Deviation from Linearity & 0,391 & 0,899 \\
\hline
\end{tabular}

Tabel 10. Hasil Uji Pretest

\begin{tabular}{lccl}
\hline Data uji & p (Sig.) & $\boldsymbol{\alpha}$ & Keputusan \\
\hline Motivasi awal kelas eks-kontrol & 0,197 & 0,05 & Tidak berbeda signifikan \\
Pretest kelas eks-kontrol & 0,590 & 0,05 & Tidak berbeda signifikan \\
\hline
\end{tabular}

Tabel 11. Hasil Uji t Motivasi Belajar Akhir

\begin{tabular}{lccc}
\hline Data uji & p (Sig.) & $\boldsymbol{\alpha}$ & Keputusan \\
\hline Motivasi belajar akhir kelas eks-kontrol & 64 & 0,05 & Ho ditolak \\
\hline
\end{tabular}

hubungan yang linier antara hasil belajar teori dengan hasil belajar praktik.

Pengujian berikutnya adalah uji hasil pretest untuk mengetahui keseimbangan kondisi awal siswa menggunakan uji t. Data hasil pengujian terhadap pretest dapat dilihat pada tabel 10 .

Sesuai hasil uji t di atas, dapat dilihat bahwa kondisi motivasi dan kemampuan praktik siswa sebelum perlakuan tidak berbeda secara signifikan.

Uji berikutnya adalah menguji hipotesis yang diajukan melalui statistik yang sesuai pada hipotesis pertama dan hipotesis kedua. Uji hipotesis pertama menggunakan teknik statistik uji t untuk mengetahui adanya perbedaan atau tidak terhadap rata-rata motivasi kelompok sampel yang mengikuti pembelajaran cooperative project-based learning dengan pembelajaran yang dilaksanakan seperti biasanya, yaitu strategi pembelajaran langsung. Uji hipotesisnya 1 dilakukan untuk menguji apakah Ho dapat ditolak atau tidak menggunakan uji t komparatif dua sampel independen menggunakan bantuan program SPSS 21. Hasilnya disajikan pada tabel 11.

Sesuai hasil perhitungan dengan uji $\mathrm{t}$ di atas, dapat dilihat bahwa nilai $\mathrm{p}<\alpha$, yaitu $0,044<0,05$. Dengan demikian dapat diputuskan bahwa Ho ditolak yang berarti terdapat perbedaan motivasi belajar siswa yang mengikuti cooperative project-based learning dengan pembelajaran langsung pada standar kompetensi "Menentukan dan memperbaiki gangguan pada sistem kerja mesin".

Berbeda dengan hipotesis pertama, hipotesis kedua diuji dengan perhitungan statistik analisis kovarian, sebab melibatkan kovariabel hasil belajar teori. Pengujian hipotesis kedua memperlihatkan adanya perbedaan hasil belajar atau tidak pada siswa yang mengikuti pembelajaran praktik dengan strategi cooperative project-based learning dibanding pembelajaran yang diterapkan selama ini yaitu pembelajaran langsung yang mempertimbangkan hasil belajar teori.. 
Tabel 12. Hasil Analisis Kovarian Hasil Belajar Praktik

\begin{tabular}{lccc}
\hline Data uji & p (Sig.) & $\boldsymbol{\alpha}$ & Keputusan \\
\hline Motivasi belajar akhir kelas eks-kontrol & 0,028 & 0,05 & Ho ditolak \\
\hline
\end{tabular}

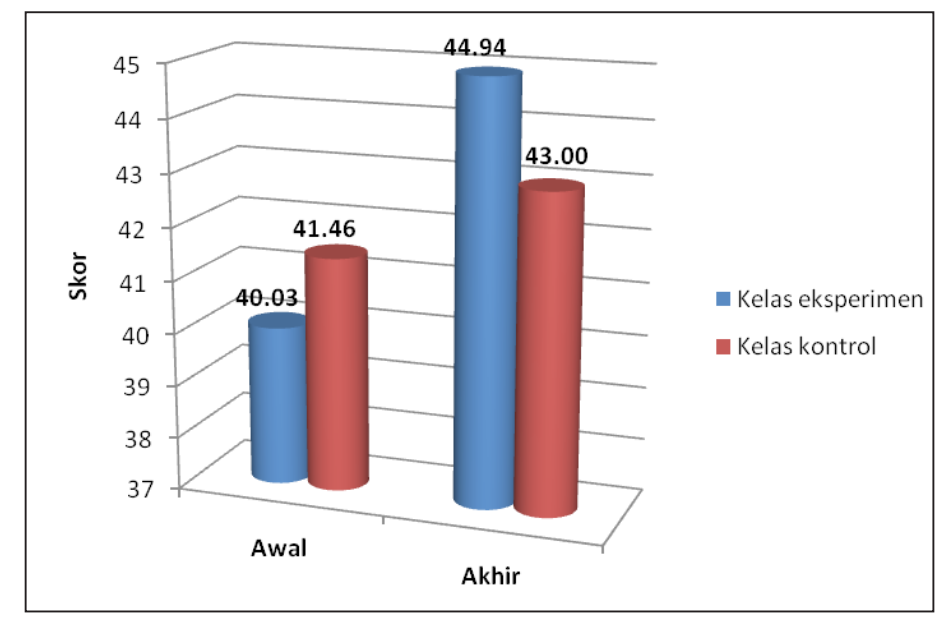

Gambar 1. Perbedaan rata-rata motivasi belajar

Uji hipotesis yang dilakukan untuk menguji apakah Ho dapat ditolak atau tidak menggunakan analisis kovarian. Berdasarkan perhitungan yang dilakukan dengan program SPSS 21, diperoleh hasil pada tabel 12.

Sesuai hasil analisis kovarian di atas, dapat dilihat bahwa nilai nilai $\mathrm{p}<\alpha$ yang ditetapkan, yaitu $0,028<0,05$. Dengan demikian diputuskan bahwa Ho ditolak dan diartikan terdapat perbedaan hasil belajar praktik siswa yang mengikuti pembelajaran cooperative projectbased learning dengan pembelajaran langsung pada praktik "Menentukan dan memperbaiki gangguan pada sistem kerja mesin" dengan mempertimbangkan kemampuan teori siswanya.

\section{Pembahasan}

Motivasi belajar akan mendukung siswa tergerak untuk belajar dan mencapai prestasinya. Oleh karena itu, timbulnya motivasi belajar merupakan pekerjaan yang tidak boleh dikesampingkan oleh seorang guru. Guru dapat mendorong motivasi belajar dengan berbagai cara, salah satunya adalah menerapkan strategi pembelajaran yang cocok, sebab strategi pembelajaran merupakan salah satu komponen pembelajaran yang secara langsung berpengaruh terhadap motivasi belajar dan hasil belajar.
Hasil uji hipotesis menunjukkan bahwa motivasi belajar siswa setelah mengikuti cooperative project-based learning berbeda secara signifikan dengan motivasi belajar siswa yang mengikuti pembelajaran langsung. Keputusan ini didasarkan pada hasil uji hipotesis menggunakan statistik uji t untuk membandingkan rata-rata motivasi belajar siswa pada kedua kelompok sampel, di mana nilai $\mathrm{p}$ hasil pengujian lebih kecil dari taraf signifikansi yang ditetapkan yaitu 0,044<0,05. Ditinjau dari skor rata-rata motivsi belajar yang dimiliki siswa, siswa yang mengikuti cooperative project-based learning cenderung lebih tinggi daripada yang mengikuti pembelajaran langsung, yaitu 44,94>43,00. Perbedaan motivasi siswa baik sebelum perlakuan maupun setelah perlakuan dapat dilihat pada gambar 1 diagram.

Terlihat dari diagram di atas, motivasi belajar awal kelompok eksperimen lebih rendah daripada kelompok kontrol. Namun, kondisi ini berkebalikan pada saat akhir perlakuan. Motivasi belajar siswa dalam praktik ketika akhir pembelajaran lebih tinggi untuk kelas yang menerapkan cooperative project-based learning. Motivasi belajar yang berbeda ini bukan karena sejak awal sudah berbeda. Hal ini dapat dilihat dari hasil uji terhadap skor 


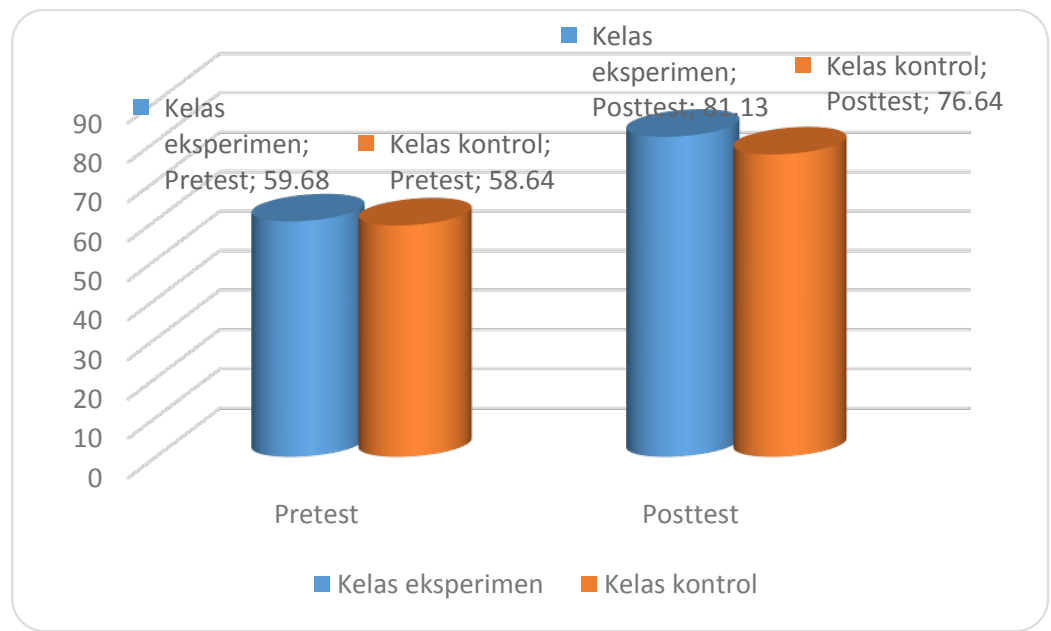

Gambar 2. Perbedaan rata-rata hasil belajar siswa

pretestnya tidak memiliki perbedaan yang signifikan antar kedua kelas tersebut. Berbeda dengan hasil terhadap pretestnya, dari hasil posttest untuk kedua kelas yang menerapkan strategi pembelajaran tersebut berbeda secara signifikan. Dengan demikian, dapat dimaknai bahwa strategi pembelajaran cooperative project-based learning terbukti lebih mampu membangun motivasi belajar siswa.

Cooperative project-based learning mampu membangkitkan motivasi belajar siswa pada praktik "Menentukan dan memperbaiki gangguan pada sistem kerja mesin". Strategi ini mampu mendukung berbagai keuntungan yang didapat melalui pembelajaran berbasis proyek dan pembelajaran kooperatif. Oleh karena itu, strategi ini menekankan ketuntasan perbaikan yang dilakukan siswa pada praktik melalui kerjasama kelompok, pemberian penghargaan, maupun peran kolaboratif guru.

Pembelajaran cooperative projectbased learning mampu membawa siswa aktif dan merasa memiliki tantangan intelektual yang lebih. Strategi ini mendorong siswa bekerjasama dalam kelompok, bertukar pikiran untuk menyelesaikan masalah, meningkatkan kepercayaan diri, serta melatih siswa menghargai perbedaan dan kekurangan siswa lain, sehingga peran teman sebaya dalam kelompok akan mendorong semangat belajar,serta mengurangi dominasi individu.

Sebaliknya, pembelajaran langsung yang diterapkan selama ini belum mampu mendorong motivasi belajar secara optimal. Hal ini dapat terjadi karena kekurangsesuaiannya strategi ini jika diterapkan pada pembelajaran dengan tuntutan kompetensi pada praktik "Menentukan dan memperbaiki gangguan pada sistem kerja mesin".

Selain pentingnya motivasi belajar, orientasi pencapaian kompetensi dengan istilah hasil belajar merupakan hal yang paling pokok merupakan indikasi suksesnya pembelajaran. Hasil belajar praktik merupakan bentuk penguasaan materi praktik setelah mengikuti pembelajaran yang diukur melalui tes praktik. Untuk mencapainya, siswa harus menguasai berbagai macam indikator pencapaian kompetensi sesuai standarnya. Pencapaian hasil belajar ini tidak lepas dengan peran strategi pembelajaran, sebab strategi pembelajaran merupakan faktor yang secara langsung mendukung pencapaian hasil belajar.

Strategi pembelajaran cooperative projectbased learning diyakini lebih sesuai untuk diterapkan pada praktik standar kompetensi "Menentukan dan memperbaiki gangguan pada sistem kerja mesin" dibandingkan dengan strategi yang diterapkan selama ini, yaitu pembelajaran langsung. Alasannya. cooperative project-based learning memiliki karakteristik yang sesuai untuk membelajarkan praktik tersebut. Sesuai hasil analisis data, dapat dilihat bahwa terdapat perbedaan hasil belajar praktik antara siswa yang mengikuti cooperative project-based learning dengan siswa yang mengikuti pembelajaran langsung meskipun hasil belajar teori disertakan. Hasil 


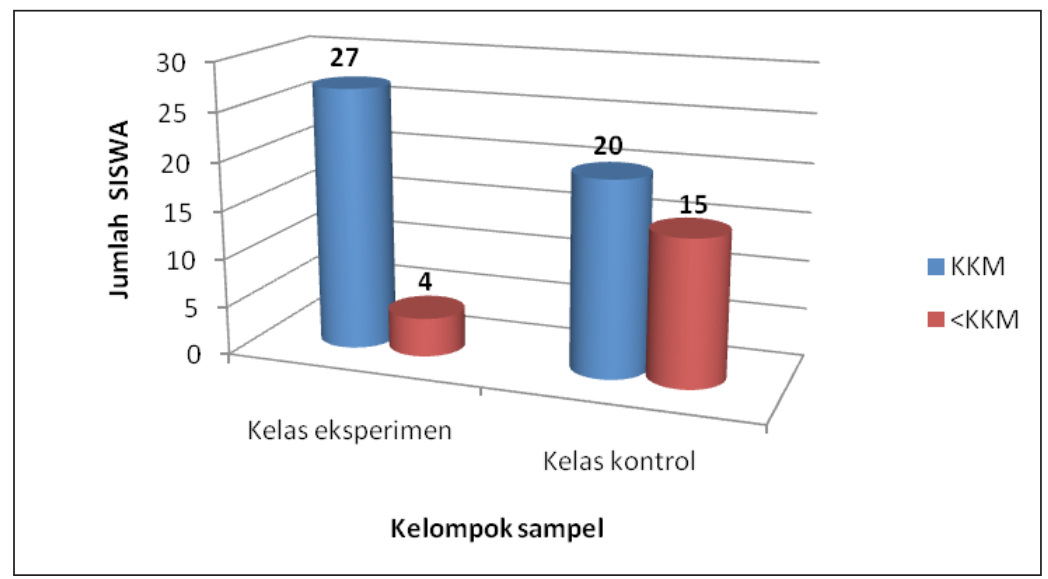

Gambar 3. Ketercapaian KKM siswa

perhitungan analisis kovarian menunjukkan bahwa nilai $\mathrm{p}$ (sig.) lebih kecil dari yang ditetapkan, yaitu $0,028<0,05$. Oleh karena itu, terdapat perbedaan yang signifikan pada pencapaian hasil belajar praktik siswa yang mengikuti cooperative project-based learning dengan siswa yang mengikuti pembelajaran langsung. Penerapan cooperative projectbased learning dapat mempengaruhi hasil belajar praktik "Menentukan dan memperbaiki gangguan pada sistem kerja mesin". Hasil tersebut juga didukung dari rata-rata ketercapaian hasil belajar siswa yang mengikuti cooperative project-based learning lebih tinggi dibanding siswa yang mengikuti pembelajaran langsung yaitu $81,13>76,64$. Perbandingan rata-rata hasil belajar tersebut dapat dilihat pada gambar 2 .

Rata-rata hasil belajar yang lebih tinggi menandakan bahwa praktik "Menentukan dan memperbaiki gangguan pada sistem kerja mesin" lebih cocok jika menerapkan cooperative project-based learning. Strategi ini menuntut orientasi pembelajaran pada pemecahan masalah, mendorong ide siswa, mengembangkan pemahaman, serta mengurangi kebingungan saat menemui masalah mesin. Di samping itu, siswa secara bebas dapat mengemukakan pendapatnya, serta menuntut tanggung jawab individu siswa. Dengan menuntut tanggungjawab pada setiap individunya, strategi ini cocok diterapkan untuk siswa kelas XII.

Kesesuaian strategi pembelajaran cooperative project-based learning juga dapat dilihat dari ketercapaian KKM antara kelas yang menerapkan kedua strategi di atas. Diagram ketercapaian hasil belajar baik untuk kelas yang menerapkan cooperative project-based learning maupun kelas yang menggunakan strategi pembelajaran langsung ditinjau dari ketercapaian KKMnya dapat dilihat pada gambar 3 .

Pada gambar 3 menunjukkan bahwa terdapat 4 siswa (13\%) yang belum mencapai KKM pada kelas yang menerapkan strategi cooperative project-based learning. Sedangkan jumlah siswa yang belum mencapai KKM untuk pembelajaran langsung adalah 15 siswa (43\%). Dengan demikian terlihat bahwa pembelajaran yang menerapkan cooperative project-based learning mampu lebih banyak siswa yang mencapai KKM, meskipun terdapat siswa yang masih belum mencapai KKM. Oleh karena itu, terbukti bahwa hasil belajar praktik siswa yang mengikuti cooperative projectbased learning lebih baik daripada siswa yang mengikuti pembelajaran langsung pada standar kompetensi "Menentukan dan memperbaiki gangguan pada sistem kerja mesin".

\section{SIMPULAN DAN SARAN}

\section{Simpulan}

Berdasarkan hasil penelitian dan pembahasan di atas, dapat disimpulkan bahwa: (1)Terdapat pengaruh penerapan cooperative project-based learning pada motivasi belajar pembelajaran praktik "Menentukan dan 
memperbaiki gangguan pada sistem kerja mesin" dibandingkan dengan pembelajaran langsung yang diterapkan selama ini pada kompetensi keahlian TKR di SMKN 1 Seyegan. Penerapan cooperative project-based learning lebih mendorong motivasi belajar siswa dibanding yang mengikuti pembelajaran langsung pada standar kompetensi tersebut, (2)Terdapat pengaruh penerapan cooperative project-based learning terhadap hasil belajar siswa pada pembelajaran praktik "Menentukan dan memperbaiki gangguan pada sistem kerja mesin" dibandingkan dengan pembelajaran langsung yang diterapkan selama ini pada kompetensi keahlian TKR di SMKN 1 Seyegan. Siswa yang mengikuti pembelajaran cooperative project-based learning mampu mencapai hasil belajar yang lebih baik dibanding yang mengikuti pembelajaran langsung pada standar kompetensi tersebut.

\section{Saran}

Berdasarkan simpulan di atas, beberapa hal yang dapat disarankan, yaitu: (1) guru dapat menerapkan strategi pembelajaran cooperative project-based learning untuk membangkitkan motivasi dan hasil belajar siswa khususnya pada praktik "Menentukan dan memperbaiki gangguan pada sistem kerja mesin", karena terbukti lebih baik dibanding pembelajaran langsung, (2) Apabila guru akan menerapkan strategi cooperative projectbased learning, hendaknya menyesuaikan kondisi siswa yang diajar, materi ajarnya, serta melakukan perencanaan, penyiapan dan mengikuti panduan pelaksanaan pembelajaran dengan cermat, (3)Sekolah perlu mendukung secara material maupun moral kepada guru dalam melaksanakan cooperative projectbased learning untuk standar kompetensi yang lain dengan mempertimbangkan materi maupun kebutuhan siswa, (4)Bagi peneliti lain, diharapkan dapat melaksanakan penelitian yang lebih baik, dengan melakukan pengontrolan variabel-variabel bebas lainnya yang masih dapat berpengaruh, sehingga validitas internal dan eksternal dapat dikontrol dengan lebih baik.

\section{DAFTAR PUSTAKA}

Anonim. (September 2012). P21 Framework Definitions, Artikel. Diambil pada tanggal 18 Mei 2013, dari http:// www.21stcenturyskills.org.

Arends, R. I \& Kilcher, A. (2010). Teaching for student learning. New York: Routledge.

Bender, W.N. (2012). Project-based learning: differentiating instruction for the $21^{\text {st }}$ century. Thousand Oaks: Corwin.

Borich, G. D. (2007). Effective teaching methods; research-based practice ( $6^{\text {th }}$ ed.). Columbus: Pearson.

Cooperstein, S. E. \& Weidinger, E. K. (2004). Beyond active learning: a constructivist approach to learning. Emerald Journal, 32, pp.141-148.

Depdiknas. (2006). Peraturan Menteri Pendidikan Nasional Nomor 23 Tahun 2006, tentang Standar Kompetensi Lulusan untuk Satuan Pendidikan Dasar dan Menengah.

Gaikindo. (2012). Penjualan mobil di Indonesia sudah mencapai 816.322 unit. http:// otomotif.kompas.com diakses tanggal 6 Juli 2013.

Killen, R. (2009). Effective teaching strategies: lesson from research and practice. South Melbourne: Thomson/Social Press.

Krathwohl, D. R., Bloom, B. S., \& Masia, B. B. (1956). Taxonomi of education objective. London: Longman Group Ltd.

Kubiszin, T dan Borich, G., (2003). Educational testing and measurement. Hoboken: John Wiley \& sons, inc.

Lazinica, A \& Calafate, C. (2009). Technology Education and Development. Vukovar: In-Teh.

Muijs, D. \& Reynolds, D. (2011). Effective teaching ( $3^{r d}$ ed.). London: SAGE Publications. 
Purwanto, M. N. (2003). Psikologi pendidikan. Bandung: PT Remaja Rosdakarya.

Rüütmann, T \& Kipper, H. (2011). Teaching Strategies for Direct and Indirect Instruction in Teaching Engineering. Proceedings of 14th International Conference on Interactive Collaborative Learning, Estonia, 107-114.

Sardiman. (2011). Interaksi \& motivasi belajar mengajar. Jakarta: PT Raja Grafindo Persada.
Schunk, D. H., Pintrich P. R., \& Meece J. L. (2010). Motivation in education. Upper Saddle River: Pearson.

Tippelt, R. \& Amoros, A. (2003). The project method in vocational training. Munich: InWEnt.

Uno, H. B. (2008). Teori motivasi \& pengukurannya. Jakarta: Bumi Aksara.

Wlodkowsky, R. J. (2008). Enhancing adult motivation to learn. San Francisco: Jossey-Bass. 